\title{
Preoperative Investigation of Malnutrition in Elective Surgery Cases and Relationship with Serum Magnesium Level
}

Elektif Cerrahi Olgularda Malnutrisyonun Preoperatif Araştırılması ve Serum Magnezyum Seviyesi ile İlişkisi

${ }^{1}$ Canan Cam Gonen, ${ }^{2}$ Ilkay Ceylan, ${ }^{3}$ Ebru Karakoc, ${ }^{4}$ Serdar Ekemen

'Department of Intensive Care, Ministry of Health Ankara City Hospital, Ankara, Turkey

${ }^{2}$ Department of Anesthesiology and Reanimation, University of Health Sciences Bursa High Specialization Training and Research Hospital, Bursa, Turkey

${ }^{3}$ Department of Anesthesiology and Reanimation, Cankırı State Hospital, Cankiri, Turkey

${ }^{4}$ Department of Anesthesiology and Reanimation, Eskisehir Osmangazi University Hospital, Eskisehir,Turkey

Correspondence:

Canan CAM GÖNEN

Department of Intensive Care, Ministry of Health Ankara City Hospital, Ankara, Turkey e-mail: cnngnn92@gmail.com

\section{Abstract}

Presence of hypomagnesemia in the perioperative period can significantly increase morbidity (1). Preoperative nutritional deficiency may accompany magnesium deficiency. The aim of this study is; To investigate malnutrition by mini nutritional assessment-short form (MNA-sf) in patients scheduled for elective surgery and to examine the relationship between magnesium level, age, gender, surgical departments, BMI and ASA classification. Patients over the age of 18 who were scheduled for elective surgery were included in the study. The study was conducted with 387 patients according to statistical power analysis. In our study, magnesium level was found to be significantly lower in inverse proportion to age only in preoperative patients hospitalized in the general surgery department. It was found that the magnesium level of preoperative male patients hospitalized in the general surgery department was significantly higher than that of female patients. It was determined that the mini nutritional screening and evaluation tests showed statistically significant correlation in all surgical departments. Malnutrition is thought to have adverse effects on morbidity in the perioperative period. It may be very useful to detect malnutrition that can be detected by hypomagnesemia with a simple test beforehand.

Keywords: Magnesium; MNA; malnutrition; MNA-SF

\section{Özet}

Perioperatif dönemde hipomagnezemi varlığı morbiditeyi önemli ölçüde artırabilir (1). Preoperatif beslenme eksikliği magnezyum eksikliğine eşlik edebilir.:Bu çalışmanın amacı; Elektif cerrahi planlanan hastalarda mini nütrisyonel değerlendirme-kısa form (MNA-sf) ile malnütrisyonun araştırılması ve magnezyum düzeyi, yaş, cinsiyet, cerrahi bölümler, BMI ve ASA sınıflaması arasındaki ilișkinin incelenmesi. Çalışmaya elektif cerrahi planlanan 18 yaş üstü hastalar dahil edildi. Çalışma istatistiksel güç analizine göre 387 hasta ile yapılmıştır. Çalışmamızda sadece genel cerrahi bölümünde yatan preoperatif hastalarda magnezyum düzeyi yaşla ters orantılı olarak anlamlı derecede düşük bulundu. Genel cerrahi servisine yatırılan ameliyat öncesi erkek hastaların magnezyum düzeylerinin kadın hastalara göre anlamlı derecede yüksek olduğu saptandı. Mini beslenme tarama ve değerlendirme testlerinin tüm cerrahi bölümlerde istatistiksel olarak anlamlı korelasyon gösterdiği belirlendi. Malnütrisyonun perioperatif dönemde morbidite üzerine olumsuz etkileri olduğu düşünülmektedir. Hipomagnezemi ile tespit edilebilecek malnütrisyonun önceden basit bir test ile tespit edilmesi çok faydalı olabilir.

Anahtar Kelimeler: Magnezyum; MNA, malnütrisyon; MNA-SF 


\section{Introduction}

Magnesium has vital functions in the human body. Presence of hypomagnesemia in the perioperative period can significantly increase morbidity (1). In addition, serum magnesium level decreases even more, especially after abdominal or orthopedic surgeries (2). Since magnesium is an absolute requirement, it should be taken in sufficient amounts with diet. Therefore, preoperative nutritional deficiency may accompany magnesium deficiency.

Malnutrition occurs in patients requiring surgery due to many factors. Preoperative malnutrition is associated with increased mortality and morbidity (3). By determining this situation, biochemical and immunological abnormalities can be corrected before surgery. The first step in detecting malnutrition is the application of screening methods (4). Nutrition screening tools have been developed for this. Mini nutritional assessment (MNA) and mini nutritional assessment short form (MNA-SF) are used for elderly patients. In addition, it has been stated that MNA-SF can be used in determining malnutrition in young and middle age group patients and adults (5).

The aim of our study is to determine the preoperative nutritional status of surgical patients using MNA-SF and to determine the hypomagnesemia that may accompany malnutrition.

\section{Material and Methods}

The study was initiated after obtaining the ethical approval of Eskişehir Osmangazi Medical Faculty Hospital, dated 18.12.2012 and numbered 21. The study was planned prospectively. After the statistical power analysis, the number of patients was planned to be 387. The study was conducted in Eskişehir Osmangazi University Faculty of Medicine Hospital with patients over 18 years of age who were scheduled for elective surgery in a month duration after obtaining ethical approval. Written consent was obtained the day before the operation. MNA and MNA-SF questionnaires were applied to the patients. Patients who did not give their consent, and those using magnesium, lithium, thyroid hormone, diuretic, amphoterecin B, aminoglycoside, alcohol and theophylline were excluded from the study. In addition, patients with diabetes mellitus and chronic renal failure were excluded from the study.

Age, gender and ASA scores of the patients were recorded. In addition, the reference range of serum magnesium levels measured on the day of malnutrition assessment was taken as $0.8-1.1 \mathrm{mmol} / \mathrm{L}$.

\section{Statistical Analysis}

Statistical package program SPSS 17 was used for statistical analysis in the study. Descriptive statistical methods (Frequency, Percent, Average, Standard deviation) were used while evaluating the study data.

Pearson's chi-square test was used to compare qualitative data. Independent samples t-test was used for comparisons between groups in case of two groups for comparison of quantitative data. One-way Anova test was used for intergroup comparisons of parameters in cases of more than two groups. Bonferroni test was used to identify the group that caused the difference. Pearson Correlation Analysis was used for the correlational analysis of quantitative data.

The results were at $95 \%$ confidence interval, $p$ $<0.05$ significance level and $\mathrm{p}<0.01$; $\mathrm{P}$ $<0.001$ was evaluated at the advanced significance level.

\section{Results}

387 patients over the age of 18 who were scheduled for elective surgery were included in the study. The dermographic distributions and ASA scores of the patients included in the study are shown in Table 1. The average age of our study was $48.97 \pm 14.01$ and the number of male patients was 187 , and the number of female patients was 200 . The ASA score distribution of the patients was 145 patients with ASA I, 91 patients with ASA II, 106 patients with ASA III and 45 patients with ASA IV, respectively. The distribution of 
patients' MNA scores among surgical patients are shown in Tables 2, 3, 4,5,6,7, departments is shown in Table 2. MNA, respectively. MNA-SF and magnesium levels of the

Table 1. Demographic data, Osmangazi $2012(\mathrm{~N}=387)$

\begin{tabular}{|c|c|c|c|c|}
\hline \multirow{2}{*}{$\begin{array}{l}\text { Age }(\text { mean }+ \text { Sd) } \\
\text { Gender }\end{array}$} & \multicolumn{4}{|c|}{$48,97 \pm 14,01$} \\
\hline & \multicolumn{2}{|c|}{ Male (n) } & \multicolumn{2}{|c|}{ Female (n) } \\
\hline & \multicolumn{2}{|c|}{187} & \multicolumn{2}{|c|}{200} \\
\hline \multirow[t]{2}{*}{ *ASA score } & ASA I (n) & ASA II (n) & ASA III (n) & ASA IV (n) \\
\hline & 145 & 91 & 106 & 45 \\
\hline
\end{tabular}

Table 2. Distribution of patients' MNA scores, Osmangazi $2012(\mathrm{~N}=387)$

\begin{tabular}{|c|c|c|c|c|c|}
\hline Surgical department & $\mathbf{N}$ & Mean: & Sd & $\mathbf{F}$ & p \\
\hline Orthopedics and traumatology & 42 & 23,190 & 4,843 & \multirow[t]{10}{*}{3,703} & \multirow{10}{*}{$0,000 * * *$} \\
\hline Cardiac surgery & 10 & 24,200 & 1,874 & & \\
\hline Gynecology and Obstetrics & 58 & 26,397 & 2,997 & & \\
\hline Thoracic surgery & 11 & 23,136 & 1,951 & & \\
\hline Ear, nose and throat surgery & 47 & 26,862 & 3,371 & & \\
\hline Plastic and reconstructive surgery & 33 & 25,712 & 3,808 & & \\
\hline Brain and neurosurgery & 30 & 25,033 & 4,204 & & \\
\hline Urological surgery & 75 & 25,653 & 4,218 & & \\
\hline General surgery & 69 & 25,804 & 3,122 & & \\
\hline Eye surgery & 12 & 23,417 & 7,824 & & \\
\hline
\end{tabular}

$M N A$, mini nutritional assessment; $M$, mean; $S d$, standard deviation; advanced statistical significance, $p<0.001 * * *$

No significant difference was found in $\mathrm{Mg}$ levels in the surgical groups according to the group variable in preoperative surgical patients $(\mathrm{F}=1.652 ; \mathrm{p}=0.099>0.05)$. A significant difference was found in the level of MNA-SF scores depending on the group variable $(F=2.354 ; p=0.014<0.05)$. The MNA-SF scores of the cases in the ENT service $(12,660 \pm 2,057)$ were found to be significantly higher than the MNA-SF scores of the cases in the orthopedic service $(10,880$ $\pm 2,787)$. The MNA-SF scores of the cases in the general surgery service $(12.350 \pm 2.099)$ were found to be significantly higher than the MNA-SF scores $(10.880 \pm 2.787)$ of the cases in the orthopedic service are shown in Table 3.

Table 3.Distribution of Patients' MNA-SF scores, Osmangazi 2012 (N = 387)

\begin{tabular}{|c|c|c|c|c|c|}
\hline Surgical department & $\mathbf{N}$ & Mean & Sd & $\mathbf{F}$ & p \\
\hline Orthopedics and traumatology & 42 & 10,881 & 2,787 & 2,354 & $0,014 *$ \\
\hline Cardiac surgery & 10 & 11,700 & 1,767 & & \\
\hline Gynecology and Obstetrics & 58 & 12,207 & 2,015 & & \\
\hline Thoracic surgery & 11 & 10,909 & 1,375 & & \\
\hline Ear, nose and throat surgery & 47 & 12,660 & 2,057 & & \\
\hline Plastic and reconstructive surgery & 33 & 12,121 & 2,190 & & \\
\hline Brain and neurosurgery & 30 & 11,867 & 2,460 & & \\
\hline Urological surgery & 75 & 12,307 & 2,552 & & \\
\hline General surgery & 69 & 12,348 & 2,099 & & \\
\hline Eye surgery & 12 & 12,750 & 1,913 & & \\
\hline
\end{tabular}


Table 4. Magnesium level, Osmangazi $2012(\mathrm{~N}=387)$

\begin{tabular}{|c|c|c|c|c|c|}
\hline Surgical department & $\mathbf{N}$ & Mean: (mmol/L) & Sd & $\mathbf{F}$ & $\mathrm{p}$ \\
\hline Orthopedics and traumatology & 42 & 0,833 & 0,148 & 1,652 & 0,099 \\
\hline Cardiac surgery & 10 & 0,765 & 0,152 & & \\
\hline Gynecology and Obstetrics & 58 & 0,845 & 0,087 & & \\
\hline Thoracic surgery & 11 & 0,805 & 0,091 & & \\
\hline Ear, nose and throat surgery & 47 & 0,798 & 0,152 & & \\
\hline $\begin{array}{l}\text { Plastic and reconstructive } \\
\text { surgery }\end{array}$ & 33 & 0,801 & 0,110 & & \\
\hline Brain and neurosurgery & 30 & 0,838 & 0,091 & & \\
\hline Urological surgery & 75 & 0,856 & 0,091 & & \\
\hline General surgery & 69 & 0,839 & 0,125 & & \\
\hline Eye surgery & 12 & 0,813 & 0,104 & & \\
\hline
\end{tabular}

M, mean; S, standard deviation; advanced statistical significance, $\mathrm{p}<0.001 * * *$

A significant difference was found in the MNA score level depending on the group variable $(F=1.652 ; p=0.099>0.05)$. The MNA scores of the cases in the obstetrics service $(26,397 \pm 2,997)$ were found to be significantly higher than the MNA scores of the cases in the orthopedic service $(23,190 \pm$ 4,843). The MNA scores of the cases in the ENT service $(26,862 \pm 3,371)$ were found to be significantly higher than the MNA scores of the cases in the orthopedic service $(23,190$ $\pm 4,843)$. The MNA scores of the cases in the urology service $(25,653 \pm 4,218)$ were found to be significantly higher than the MNA scores of the cases in the orthopedic service $(23,190 \pm 4,843)$. The MNA scores of the cases in the general surgery service $(25,804 \pm$ 3,122 ) were found to be significantly higher than the MNA scores of the cases in the orthopedic service $(23,190 \pm 4,843)$ are shown in Table 2.
In cases in the general surgery service; A negative correlation of $28.6 \%$ was found between age and $\mathrm{Mg}$ levels $(\mathrm{r}=-0.286 ; \mathrm{p}=$ $0.017<0.05$ ). In the patients in the general surgery ward, it was found that the Mg level decreased as the age got older. There was no statistically significant relationship between $\mathrm{Mg}$ and Age in other groups ( $p>0.05$ ). There was no statistically significant relationship between $\mathrm{Mg}$ and Age in all cases ( $\mathrm{p}>0.05$ ).

There was no statistically significant relationship between $\mathrm{Mg}$ and MNA-SF on a group basis $(p>0.05)$. There was no statistically significant relationship between $\mathrm{Mg}$ and MNA-SF in all cases ( $\mathrm{p}>0.05$ ). Table 5. No statistically significant relationship was found between $\mathrm{Mg}$ and MNA on the basis of the group ( $>>0.05)$. No statistically significant relationship was found between $\mathrm{Mg}$ and MNA in all cases ( $>00.05)$. Table 6 .

Table 5 Patients' Mg levels and its relationship with MNA-SF, Osmangazi 2012 (N=387)

\begin{tabular}{llll}
\hline \multicolumn{1}{c}{ Surgical department } & n & r & p \\
\hline Orthopedics and traumatology & 42 & $-0,235$ & 0,134 \\
\hline Cardiac surgery & 10 & $-0,247$ & 0,492 \\
\hline Gynecology and Obstetrics & 58 & 0,074 & 0,580 \\
\hline Thoracic surgery & 11 & 0,204 & 0,548 \\
\hline Ear, nose and throat surgery & 47 & 0,061 & 0,682 \\
\hline Plastic and reconstructive surgery & 33 & $-0,089$ & 0,624 \\
\hline Brain and neurosurgery & 30 & 0,337 & 0,069 \\
\hline Urological surgery & 75 & 0,167 & 0,151 \\
\hline General surgery & 69 & 0,116 & 0,345 \\
\hline Eye surgery & 12 & $-0,014$ & 0,966 \\
\hline All cases & 387 & 0,036 & 0,481 \\
\hline
\end{tabular}

MNA-SF;mini nutritional assessment short form, Mg levels (mmol / L) unit, $r$; correlation coefficient 
Table 6 Patients' Mg levels and its relationship with MNA, Osmangazi 2012 (N=387)

\begin{tabular}{lccc}
\hline \multicolumn{1}{c}{ Surgical department } & n & r & p \\
\hline Orthopedics and traumatology & 42 & $-0,212$ & 0,177 \\
Cardiac surgery & 10 & $-0,399$ & 0,254 \\
Gynecology and Obstetrics & 58 & 0,048 & 0,720 \\
\hline Thoracic surgery & 11 & 0,036 & 0,917 \\
\hline Ear, nose and throat surgery & 47 & 0,007 & 0,965 \\
\hline Plastic and reconstructive surgery & 33 & $-0,115$ & 0,523 \\
Brain and neurosurgery & 30 & 0,317 & 0,088 \\
Urological surgery & 75 & 0,198 & 0,089 \\
General surgery & 69 & 0,101 & 0,407 \\
\hline Eye surgery & 12 & 0,051 & 0,875 \\
All cases & 387 & 0,027 & 0,594 \\
\hline
\end{tabular}

MNA; mini nutritional assessment, Mg levels (mmol / L), $r$, correlation coefficient, statistical significance; $p<0.05$

In cases in the orthopedic service; A significant positive correlation was found between MNA and MNA-SF at the level of $81.9 \%(r=0.819 ; p=0.000<0.001)$ Table 7 . In cases in the cardiovascular surgery service; A positive significant correlation was found between MNA and MNA-SF at the 69.1\% level $(r=0.691 ; p=0.027<0.05)$ Table 7 . In the cases in the obstetrics service; A significant positive correlation was found between MNA and MNA-SF at the $84.6 \%$ level $(r=0.846 ; p=0.000<0.001)$ Table 7. In cases in the thoracic surgery service; A significant positive correlation was found between MNA and MNA-SF at the 78.8\% level $(r=0.788 ; p=0.004<0.01)$ Table 7. In cases in the otorhinolaryngology service; A significant positive correlation was found between 92\% MNA and MNA-SF ( $r=0.920$; $p=0.000<0.001)$ Table 7 . In the cases in the plastic surgery service; A significant positive correlation at the level of $90 \%$ was found between MNA and MNA-SF $(r=0.900 ; p=$ $0.000<0.001)$ Table 7 . In cases in the neurosurgery service; There was a significant positive correlation between MNA and MNA$\mathrm{SF}$ at the $94.8 \%$ level $(\mathrm{r}=0.948 ; \mathrm{p}=0.000$ $<0.001)$ Table 7.

Table 7 Relationship between patients' MNA-SF and MNA scores, Osmangazi 2012 (N=387)

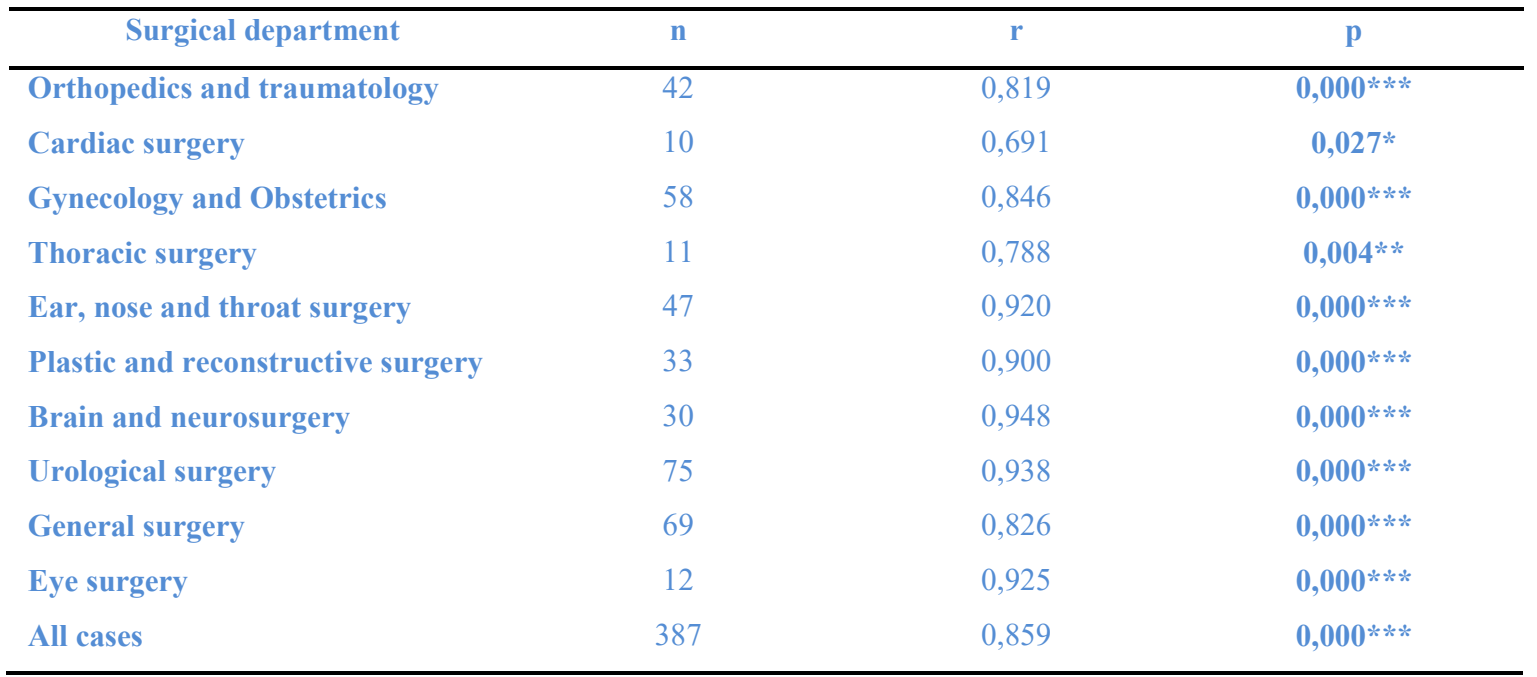

MNA; mini nutritional assessment, MNA-SF; mini nutritional assessment short form, $r$; correlation coefficient, statistical significance; $* p<0,05, * * p<0,01, * * * p<0,001$ 
A positive significant relationship was found between MNA and MNA-SF at the level of $93.8 \%$ in cases in the urology service $(\mathrm{r}=$ $0.93 .8 ; p=0.000<0.001)$ Table 7 . In the cases in the general surgery service; A significant positive correlation was found between MNA and MNA-SF at the level of $82.6 \%(r=0.826$; $\mathrm{p}=0.000<0.001)$ Table 7.A positive significant relationship was found between MNA and MNA-SF at the level of $92.5 \%$ in patients in the eye service $(\mathrm{r}=0.92 .5 ; \mathrm{p}=$ $0.000<0.001)$ Table 7. In all cases; A significant positive correlation was found between MNA and MNA-SF at the level of $85.9 \%(r=0.859 ; \mathrm{p}=0.000<0.001)$ Table 7 .

\section{Discussion and Conclusion}

It is known that the duration of hospital stay is shortened and postoperative outcomes are improved in patients whose nutritional status is optimized in the preoperative period (3). In the preoperative period, hypomagnesemia is common and is associated with malnutrition (6). In countries with middle-low income, the detection of malnutrition and associated electrolyte disturbances can be useful in surgical patients and contribute to the appropriate use of resources (3).

Preoperative malnutrition may arise from the primary disease that causes surgery or may result from completely different reasons (7). Malnutrition caused by primary disease is generally seen in cancer patients. The main secondary reasons are the decrease in oral intake and high ASA score due to old age (7).

In our study, we used MNA and MNA-SF to determine the risk of preoperative malnutrition. Thus, we thought that a rapid malnutrition risk assessment could be made in the preoperative period. MNA-SF is a sixquestion test that can be applied on an outpatient basis in outpatient settings and is recommended for use especially in the elderly (8). The average age of the patients included in our study is 49, and they consist of a relatively young age group. It has been shown that MNA-SF values are associated with the determination of nutritional status and mortality due to malnutrition in the youngmiddle age group (1), (9). In addition, the measurement of middle-upper arm diameter and the MNA-SF combination were found to be successful in detecting malnutrition in young and middle-aged hospitalized patients. It has been stated that it can be applied in this age group due to its ease of use (1), (5). In our study, it was observed that $24 \%$ of 387 patients operated in different surgical branches were under the risk of malnutrition when evaluated with MNA-SF and $17 \%$ when evaluated with MNA. A statistically significant positive correlation was found between MNA values and MNA-SF values in all preoperative surgical cases. In our study, it was determined that the MNA-SF form could be used in all preoperative elective surgery group cases to predict malnutrition in outpatient clinic conditions instead of the longer form MNA. When we look at the surgical branches, when the mean MNA score of the groups were compared, the patients who will undergo orthopedics, thoracic surgery and eye surgeries were found to be at risk of malnutrition. According to the mean MNA-SF score, orthopedics, cardiovascular surgery, thoracic surgery, and neurosurgery patients were found to be at risk of malnutrition. When both scoring systems are evaluated, it can be said that the sensitivity of MNA-SF values is higher.

Magnesium deficiency was detected in $7-11 \%$ of hospitalized patients, and it was observed that $40 \%$ had accompanying hypokalemia, hypophosphothemia, hyponatremia and hypocalcemia (10). Therefore, it may be important to detect hypomagnesemia in the perioperative period in patients with malnutrition, which may lead to significant consequences in anesthesia management (1012).

Known causes of hypomagnesemia in surgical patients; decreased dietary intake, poor gastrointestinal absorption, increased loss of the gastrointestinal tract, alcoholism, diabetes mellitus and increased renal loss (12). In addition, it is important to detect it in the perioperative period due to its interaction with agents such as anesthetic agents, diuretics, thiazides, and valproic acid (10). Although the height of the intracellular amount of magnesium in general is known, rapid mobilization of intracellular magnesium stores and intracellular magnesium stores to the extracellular area is not possible. Therefore, a 
negative magnesium balance rapidly causes hypomagnesemia (10). In our study, when we looked at hypomagnesemic conditions that we may encounter in patients with possible malnutrition risk during the perioperative period and that may cause complications in the perioperative process, hypomagnesemia was not encountered in the laboratory. However, the magnesium level of cardiovascular surgery patients was found to be lower than the other groups, although it was not statistically significant. Postoperative arrhythmia and low cardiac output may occur, since hypomagnesemia, which is present after surgery, especially in cardiac surgeries, can reach up to $70 \%$ in the postoperative period (10), (13). For this reason, its importance increases in patients who have undergone this type of surgery. Finally, there was no relationship between MNA-SF and MNA and magnesium levels in patients with malnutrition risk. This may be due to the fact that our patients are at risk of malnutrition, not malnutrition. It can also be interpreted as a result of the possibility that blood magnesium levels were checked and normalized before surgery.

The main limitation of our study is that the risk of malnutrition is not supported by other malnutrition scores. In addition, patients

\section{REFERENCES}

1. Do SH. Magnesium: A versatile drug for anesthesiologists [Internet]. Vol. 65, Korean Journal of Anesthesiology. Korean Society of Anesthesiologists; 2013 [cited 2021 Mar 7]. p. 48 .

2. Parotto M, Djaiani G. Perioperative Hypomagnesemia and Increased Postoperative Morbidity and Mortality: Myth or Reality? [Internet]. Vol. 33, Journal of Cardiothoracic and Vascular Anesthesia. W.B. Saunders; 2019 [cited 2021 Mar 5]. p. 480-1.

3. Carli F, Gillis C. Surgical patients and the risk of malnutrition: preoperative screening requires assessment and optimization [Internet]. Canadian Journal of Anesthesia. Springer; 2021 [cited 2021 Mar 5]. p. 1-5.

4. Salah D. Perioperative nutrition to enhance recovery after surgery. Ain-Shams $J$ Anaesthesiol [Internet]. 2016 [cited 2021 Mar 2];9:469.

5. Asiimwe SB, Muzoora C, Wilson LA, Moore CC. Bedside measures of malnutrition and association with mortality in hospitalized adults. Clin Nutr [Internet]. 2015;34:252-6. determined to be at risk with MNA-SF were not followed up intraoperatively and postoperatively. Therefore, possible complications associated with malnutrition and hypomagnesemia have not been identified.

As a result; hypomagnesemia is an electrolyte disorder that may accompany malnutrition. Considering that this situation alone has a significant effect on morbidity and mortality in the peroperative period, early detection of its association with malnutrition may have positive returns. No significant correlation was found between MNA score and MNA-SF score and magnesium levels. Although a correlation was shown between hypomagnesemia and malnutrition, the relationship between MNA and MNA-SF scores could not be demonstrated. A significant positive correlation was found between MNA score and MNA-SF score in all preoperative elective surgery cases in detecting preoperative malnutrition. MNA-SF may be more suitable for the detection of malnutrition in preoperative elective surgery patients in polyclinic conditions in terms of easy applicability and time saving. This application may have positive results in the preoperative early detection and treatment of malnutrition in patients scheduled for surgery.

6. Whittaker JD, Downes F, Becker H, Garnham A, Wall M. Influence of Perioperative Serum Magnesium for Cardiac and Noncardiac Morbidity and Mortality Following Emergency Peripheral Vascular Surgery. J Cardiothorac Vasc Anesth [Internet]. 2019 Feb 1 [cited 2021 Apr 15];33:474-9.

7. Benoist $\mathrm{S}$, Brouquet A. Nutritional assessment and screening for malnutrition. J Visc Surg [Internet]. 2015;152: S3-7.

8. Taş Gülen, Şule, et al. KOAH'da Nutrisyonel Durumun Değerlendirmesinde Mini Nutrisyonel Anketin Kullanılabilirliği ve Solunum Fonksiyon Parametreleriyle İlişkisi. Kocaeli Tıp Dergisi, 2017, 6.2: 38-42.

9. Holvoet E, Vanden Wyngaert K, Van Craenenbroeck AH, Van Biesen W, Eloot S. The screening score of Mini Nutritional Assessment (MNA) is a useful routine screening tool for malnutrition risk in patients on maintenance dialysis. Bulduk S, editor. PLoS One [Internet]. 2020 Mar 4 [cited 2021 Apr 13];15: e0229722. 
10. Soave P, Conti G, Costa R, Arcangeli A. Magnesium and Anaesthesia. Curr Drug Targets. 2009;10:734-43.

11. Parotto M, Djaiani G. Perioperative Hypomagnesemia and Increased Postoperative Morbidity and Mortality: Myth or Reality? [Internet]. Vol. 33, Journal of Cardiothoracic and Vascular Anesthesia. W.B. Saunders; 2019 [cited 2021 Mar 7]. p. 480-1. 12. Djagbletey R, Boni F, Phillips B, Adu-Gyamfi Y, Aniteye E, Owoo C, et al. Prevalence and predictive factors of preoperative hypomagnesaemia among adult surgical patients in a large tertiary hospital in Ghana. BMC Anesthesiol [Internet]. 2015 Oct 6 [cited 2021 Mar 5];15.

12. Jannati M, Shahbazi S, Eshaghi L. Comparison of the efficacy of oral versus intravascular magnesium in the prevention of hypomagnesemia and arrhythmia after CABG. Brazilian $J$ Cardiovasc Surg. 2018;33:448-53. 